\title{
198STE BESTUURSVERGADERING
}

\author{
GEHOUDEN 15 MAART 1879.
}

Tegenwoordig de heeren van Rappard, van Goltstein, van der Gon Netscher, Lammers van Toorenburg, Humme, Meinsma, Niemann, Kern, Robidé van der Aa, Corns. de Groot en Wijnmalen. Afwezig de heer Mirandolle.

De Voorzitter deelt mede, dat, terwijl de heer van der Gon Netscher reeds op de Algemeene Vergadering zich de op hem gevallen keuze van Bestuurder heeft laten welgevallen, van de heeren van Goltstein en Lammers van 'Toorenburg missives zijn ontvangen, waarbij zij verklaren de benoeming tot leden van het Bestuur aan te nemen.

De Voorzitter heet de drie nieuw gekozen Bestuurders, ter vergadering tegenwoordig, hartelijk welkom en beveelt de belangen van het Instituut in hunne trouwe en voortdurende zorg aan.

Hierna worden de notulen van het verhandelde in de vorige vergadering gelezen en goedgekeurd.

Eveneens worden de notulen der Algemeene jaarlijksche Vergadering, den 22en Februari ll. gehouden, medegedeeld en voorloopig vastgesteld ter opneming in de "Bijdragen" vau het Instituut.

Overeenkomstig de bepaling, vervat in het eerste lid van art. 2 van het Reglement gaat de vergadering over tot de verkiezing van een Voorzitter, Onder-Voorzitter, Penningmeester en Secretaris.

Op voorstel des heeren Corns. de Groot wordt bij acclamatie de heer van Rappard tot Voorzitter herbenoemd, die zich bereid verklaart die betrekking opnieuw te aanvaarden.

Tot Onder-Voorzitter wordt met meerderheid van stemmen 
benoemd de heer van Goltstein, die deze keuze zich laat welgevallen en waarmeê de Voorzitter de vergadering gelukwenscht.

Overeenkomstig het voorstel des Voornitters worden vervolgens, zonder hoofdelijke stemming, bij acclamatie, de heeren Humme en Wijnmalen tot Peuningmeester en Secretaris herbenoemd.

De Voorzitter deelt mede, dat zijn ingekomen:

a. Missives van de heeren: mr. J. Baron d'Aulnis de Bourrouill, G. F. W. Borel, Jhr. mr. W. M. de Brauw, mr. M. Coster, A. P. Godon, J. Hudig Dz., mr. W. van der Kaaij, Jhr. mr. C. van Panhuys, O. van Rees, G. du Rey van Beest Holl, W. Schagen van Leeuwen, H. J. Snelleman, dr. J. S. Speijer, dr. N. P. van der Stok, dr. D. Veth, E. de Waal, Jhr. H. O. Wichers en Jhr. mr. H. van der Wijck, allen houdende kennisgeving van de aanvaarding van het lidmaatschap.

Voor kennisgeving aangenomen, terwijl besloten wordt:

10. te voldoen aan het verzoek des heeren d'Aulnis de Bourrouill, die ingevolge art. 5 van het Bibliotheeks-reglement een exemplaar verlangt van de inventarissen der bibliotheken, voor zoover deze althans gedrukt zijn; en

20. den heer N. P. van der Stok te kennen te geven, dat de in ziju schrijven bedoelde door hem bewerkte topographische schets van het eiland Saleyer niet in de Bijdragen van het Instituut, maar in het door het Bat. Genootschap uitgegeven Tijdschrift voor Indische taal- land- en volkenkunde is opgenomen, zoodat hem daarvan moeielijk exemplaren kunven worden uitgereikt.

b. Eene missive van den heer A. Blussé, te Dordrecht, verzoekende, ofschoon gevoelig voor de eer der benoeming tot lid van het Instituut, de zaak in nadere overweging te nemen.

c. Missives van de heeren F. N. Nieuwenhuijzen en G. M. Ver:pijck, houdende bericht dat zij het aangeboden lidmaatschap niet kunnen aanvaarden.

De missives, sub $b$ en $c$, worden voor kennisgeving aangenomen.

Door den Secretaris-Bibliothecaris wordt mededeeling gedaan 
van de titels der nieuw verworven aanwinsten der bibliotheek door geschenken Hierbij wordt voorgelezen een schrijven van het Ministerio de Fomento, te Madrid, ten geleide van een geschrift over de overblijfselen van Columbus in de Cathedraal van St. Domingo.

Wordt besloten voor dit geschenk den dank der vergadering te betuigen.

Ter tafel wordt gebracht een schrijven van den heer A. J.C. Geerts, te Yokohama, van 27 Jauuari ll. waarin hij zich bereid verklaart het zijne bij te dragen tot de bevordering van Nederlandsche studiën over het oosten, voor zooveel rijne kennis en beschikbare tijd dit toelaten, terwijl hij, eer hij eenige japansche werken van nieuweren datum aan de bibliotheek van het Instituut toezendt, daaromtrent gaarne eenige inlichtingen begeert. Bepaaldelijk over de vraag of men boeken, tijdschriften enz. verlangt, die in de laatste jaren door de Regeeringsbureau's zijn uitgegeven in de Japansche taal (dat wil zeggen gedrukt met chineesche karakters), dan wel alleen zoodanige korte rapporten, pamphletten, enz., die in eene vreemde taal (Engelsch) over de Japansche instellingen van bestuur zijn openbaar gemaakt. Terwijl het getal van eerstgenoemde werken, wier inhoud natuurlijk alleen voor deskundigen verstaanbaar is, zeer aanzienlijk mag genoemd worden, is echter dat der tweede serie veel geringer, en de boeken zelve zijn van zeer kleinen omvang. Bovendien zou nog eene andere serie wel waard zịn in eene bibliotheek over de landen van het oosten te figureeren, en wel die van nieuwere Japansche boeken bij het lager en middelbaar onderwijs in gebruik en die door het ministerie van onderwijs zijn - uitgegeven. Men zou trachten zooveel mogelijk gouvernementspublicatiën machtig te worden, welke niet in den handel verkrijgbaar gesteld zijn.

$\mathrm{Na}$ gedachtenwisseling wordt besloten den heer Geerts, onder dankzegging voor zijne welwillende letteren en belangstelling in de bibliotheek van het Iustituut, te kennen te geven, dat de drie door hem genoemde seriën van werken ook naar het oordeel van het Bestuur voor de boekerij hoogst begeerlijk zijn, weshalve het Bestuur, zoo het niet vreest misbruik te maken van de betoonde welwillendheid, gaarne zou wenschen in het bezit gesteld te worden van die reeksen van Japansche geschriften. En mochten de pogingen om ze kosteloos van de Japansche 
bureaux te verkrijgen gelukkig slagen, het spreekt wel vau zelf dat het Instituut gaarne de kosten der verzending op zich wil nemen.

Wat verder 't verzoek des heeren Geerts betreft om een catalogus der Instituutsboekerij te mogen ontvangen, hem zal worden medegedeeld, dat deze nog niet gedrukt is, doch voor de pers wordt gereed gemaakt.

Eindelijk wordt acte genomen van de verklaring van den geeerden briefschrijver, dat hij zich gaarne wenscht aan te sluiten aan het Instituut hetzij als lid of als correspondent, indien daartegen geene bezwaren bestaan. Met algemeene stemmen vereenigt zich de vergadering met het voorstel des Voorzitters om den heer Geerts onder de correspondeerende leden van het Instituut op te nemen en wordt den Secretaris opgedragen hem van dit besluit kennis te geven.

Bij een schrijven van den 26 Februari ll. noodigt de jongst opgerichte Societé de Géographie de l'Est, te Nancy, het Instituut uit eene ruiling van wederzijdsche uitgaven te doen plaats hebben.

$\mathrm{Na}$ gedachtenwisseling wordt besloten aan dit genootschap te berichten, dat het doel dat het zich voorstelt, te ver afwijkt van dat, 't welk het Instituut beoogt.

Door den Secretaris wordt ter tafel gebracht een schrijven van den heer Mart. Niihoff, waarin hij de vraag doet, of er mogelijkheid bestaat dat hem geleverd worden een zeker aantal exemplaren van den Javaanschen tekst van de onlangs door het Instituut uitgegeven werken: de Javaansche vertellingen, bewerkt door Dr. Palmer van den Broek en Humme's Abiåså; en, zoo hieraan mocht kunnen worden voldaan, tegen welken prijs deze afzonderlijke teksten van beide werken zouden kunnen geleverd wordeu bij eene bestelling van 1000,2000 en 4000 exx. van ieder, in losse bladen; alsmede ook in hoeveel tijd na eene eventueele bepaalde bestelling de levering van een en ander zou kunnen geschieden.

$\mathrm{Na}$ breedvoerige toelichting dezer aanvrage door den Secretaris met opgave tevens vau den prijs, waarvoor de beide genoemde werken zouden kunuen worden gedrukt, wordt besloten den heer Nijhoff mede te deelen dat hij het Instituut bereid zal vinden de afzonderlijke teksten dier werken te leveren in losse bladen en wel; 
10. van het eerstgenoemde werk, hij eene bestelling van

1000 exempl. tegen $f 0.75$ per ex.

$2000 "$ " $"$
3000 "
4000 en meer ex.
0.65 "

20. van het iweede werk, bij eene bestelling van

1000 exempl. tegen $f 0.30$ per ex.

$2000 "$ " "
3000 "
4000 en meer ex.
$0.25 "$ " "

De levering dezer teksten kan voorts geschieden uiterlịk vier maanden na de onderteekening van het contract, hij eventueele bestelling op te maken, terwijl de betaling aan het Instituut geschiedt drie maanden na aflevering van het gevraagde.

Ter voldoening aan het voorschrift, vervat in de voorlaatste alinea van art. 15 van het Bibliotheeks-Reglement brengt de Secretaris-Bibliothecaris ter tafel een door hem gesteld verslag van deu staat der bibliotheken van het Instituut en Indisch Genootschap, waaraan eene lijst is toegevoegd van de ten geschenke ontvangen en aangekochte handschriften en boekwerken.

Overeenkomstig het voorstel van den Voorzitter wordt de Bibliothecaris daarvoor dank gezegd en tevens besloten dat het verslag ter kennis van de leden van het Instituut zal worden gebracht door plaatsing in de Bijdragen.

De Secretaris herinnert aan het verzoek des heeren von Rosenberg, in de Algemeene Vergadering voorgedragen, om, ten behoeve van het buitenlandsch lid, den Graaf Meyners d'Estrey, een exemplaar te mogen ontvangen van de uitgave zijner reizen naar Gorontalo en de Zuid-Oostereilanden. Overeenkomstig zijn voorstel wordt goedgekeurd daaraan te voldoen.

Door den heer Quarles van Ufford was in de Algemeene Vergadering de wensch uitgesproken, dat het groote open muurvak in de vergaderzaal worde versierd met een der grootste en beste kaarten van den Nederlandsch-Iudischen Archipel. Uit de gedachtenwisseling, die hierover plaats heeft, blijkt, dat de vergadering dien wensch niet deelt zoowel op grond der overweging dat daardoor het eigenaardig karakter der zaal zou te loor gaan, als net het oog op het bezwaar om eene dergelijke kaart te verkrijgen. 
Eveneens vindt bij de vergadering geen bijval, als zijnde in strijd met het pas herziene Reglement, het mede in de Algemeene Vergadering geopperd denkbeeld om het jaarlijksch verslag vóór het houden dier jaarlịksche bijeenkomst te doen drukken en aan de leden rond te deelen.

Het Bestuurslid, Niemann, komt terug op den door hem in de Algemeene Vergadering uitgesproken wensch om de bibliotheek meer dan tweemalen 's weeks toegankelijk te stellen.

$\mathrm{Na}$ gedachtenwisseling wordt besloten aan dien wensch gevolg te geven en, overeenkomstig art. 3 van het Bibliotheeks-reglement, aan het Bestuur van het Indisch Genootschap in overweging te geven, te beginnen met 1 Mei a. s. de boek- en andere verzamelingen, met uitzondering van Zon- en feestdagen, dagelijks open te stellen van des voormiddags 12 tot des namiddags 4 ure.

Door den heer Kern wordt, namens het nieuwbenoemde lid Dr. J. L. Speyer, te Amsterdam, aangeboden een opstel, getiteld: "Beınerkungen zu den grhyasûtra", en tevens der vergadering in overweging gegeven het te doen opnemen in het eerstvolgend nommer der Bijdragen. Zonder beraadslaging vereenigt de vergadering zich met dit voorstel.

De Voorzitter stelt hierna opnieuw aan de orde de reeds in de vorige vergadering besproken vraag of het niet wenschelijk zou zijn zich bij een adres te wenden tot de Volksvertegenwoordiging ten einde haar bekend te maken met de bezwaren, die uit de aanueming van het wetsontwerp tot heffing eener belasting op de goederen in de doode hand zouden ontstian voor de wetenschappelijke instellingen in het algemeen en voor het Instituut in 't bijzonder, dat daardoor zwaar zal gedrukt worden.

$\mathrm{Na}$ langdurige beraadslaging wordt met meerderheid van stemmen in ontkennenden zin beslist.

Niets meer hierna aan de orde zijnde, wordt de vergadering doer den Voorzitter gesloten. . 